\title{
ICT Integration in Teaching and Learning in Secondary Schools in Tanzania: Readiness and Way Forward
}

\author{
Lucian V. Ngeze
}

\begin{abstract}
The use of Information and Communication Technologies (ICTs) in teaching and learning has brought new teaching and learning experience to both teachers and students in many countries. Tanzania has made several efforts to achieve this but little has been done to determine the readiness of our schools and teachers in terms of ICT infrastructure and possession of other gadgets to help in the integration of ICT in education. This study aimed at looking into the readiness of Secondary Schools to successfully integrate ICT in teaching and learning activities, and teachers in terms of knowledge, skills and possession of ICT devices. Data were collected from 202 teachers selected from 32 Secondary Schools from all the Educational Zones in Tanzania. The study revealed that most schools do not have ICT infrastructure in place. In schools where ICT infrastructure is present, student to computer ratio is very high. On the other hand, teachers are ready to use ICT in their teaching and learning activities if and only if they have the skills and knowledge to do so. The findings revealed that most of the secondary school teachers $\mathbf{( 7 7 . 0 \% )}$ now possess either a laptop or a smartphone or both. This is an implication that they are ready to use such tools in the teaching and learning process if they are directed how best they can be used. The study recommends the Ministry of Education, Science, Technology and Vocational Training (MoESTVT) to increase the effort in training teachers on ICT, setting up adequate ICT infrastructure in many schools and setting up a framework for the implementation of the same.
\end{abstract}

Index Terms-E-readiness, ICT, ICT integration, ICT in teaching and learning.

\section{INTRODUCTION}

The advances in Information and Communication Technologies (ICTs) have brought many changes in the economic and social life. ICT has been taken as an enabler of many services that lead to individual and national development. It brings advantages in many sectors, which in turn bring about national development. International leaders, donors and funders are also supporting the integration of ICT in many areas that promote social development and innovation [1]. In the area of education, improved school administration and increased performance are some of the advantages of such ICT integrations. The Tanzania Development Vision 2025 [2] among other things, stresses on the importance of having a well learned and educated society by 2025 which will contribute to the national development. ICTs are bringing many opportunities for achieving the goals of the Vision. In the education sector, ICTs have changed the pedagogical practices. It is through the use of ICT that

Manuscript received March 8, 2016; revised May 19, 2016.

L. V. Ngeze is with the University of Dodoma, P.O. Box 490 Dodoma, Tanzania (e-mail: lucianngeze@yahoo.com). innovation and creativity is promoted in many areas of development.

According to the National Bureau of Statistics [3], Tanzania has a total of 4,753 secondary schools as of 2015, of which 3,692 are public and 1,061 are private. The use of ICT in teaching and learning is still low and is hindered by many factors including lack of ICT devices and power problems. The Government through MoESTVT has implemented several programmes and initiatives that aim at integrating ICT in the teaching and learning process. Such initiatives include National Programme on ICT for Secondary School Teachers [4]; the e-Schools Project and the introduction of ICT Curriculum in Secondary schools. However, the readiness of secondary schools to effectively integrate ICT in teaching and learning and of teachers in terms of knowledge and skills has not yet been fully explored. This paper looks into the readiness of schools in terms of infrastructure present and the skills and ICT gadgets possessed by secondary school teachers towards ICT integration in teaching and learning and the way forward towards successful ICT usage in schools.

\section{LITERATURE REVIEW}

There have been many research works done in the areas of ICT application in education. These have pointed out many useful applications in the teaching and learning process. It is has been shown that the use of ICT in teaching and learning helps in improving the teaching and learning activities of the teachers and students [5]. If the entire necessary ICT infrastructure for implementation is in place, and that teachers are well trained to help students in their learning activities using ICT, it is true that the learning experience of students becomes enriched.

National ICT Policy [6] stipulates that ICT enhances effective delivery of education. However, lack of programmes for training teachers on different ICT tools and technologies was identified as a major reason to the implementation of ICT in Secondary Schools. The policy aims at improving the quality of delivering education and training in all areas including distance learning. ICT Policy for Basic Education [7] declares that the integration of ICT in teaching and learning will empower teachers, educators, school managers and leaders to use ICT effectively in their day to day activities leading to improved quality of education. The Government has invested heavily on ICT in education initiatives, including provision of ICT training to Secondary school teachers and School Quality Assurers and supply of some ICT equipment and tools in selected schools. Many programmes (Tanzania Beyond Tomorrow, e-Schools Project) have been put in place to help increase access to ICT infrastructure in schools. These 
initiatives have contributed to the use of ICT in teaching and learning and in performing school administrative tasks in the selected schools [4] More efforts are being made by the Government through the Ministry of Education, Science, Technology and Vocational Training to equip schools with ICT infrastructure and training.

A study made by Ismail, [8] on teachers perception on the use of technology in teaching languages showed that teachers use of ICT in teaching can help to improve their own teaching practices which in turn may promote students' learning. This is evident from the results obtained in the survey that was done. According to [9], the access of ICT resources made teachers increase the frequency in using them. This implies that, if ICT devices and tools are available, teachers will always tend to use them frequently. They use ICT tools in teaching included preparation of notes, teaching-learning materials, examinations and searching materials with students from computers connected to the Internet.

\section{MethodOLOGY}

Open-ended and closed-ended questionnaire was used to collect responses from 202 Secondary School teachers selected from 32 Secondary Schools in Tanzania. The questions were divided into four categories, each with its objective. The first part aimed at determining the ICT knowledge of the teachers on the topics they were taught in two different cycles as shown in Table I. The second part aimed to know the type of ICT gadgets possessed by the teachers (smartphones and laptops) in Secondary Schools. Having known the ICT knowledge level and possession of ICT devices, questions in the third part asked teachers on how they can use their ICT skills and knowledge. The last part of the questionnaire asked to know the physical ICT infrastructure existing in schools, the number of students in schools, the class size and the way infrastructure can be shared among teachers and students during teaching and learning process. The questionnaire formed the basis from which analysis and discussion were made on the readiness of ICT integration in teaching and learning in Secondary schools.

\section{RESEARCH FINDINGS}

United Nations Educational, Scientific and Cultural Organization [10] highlights the minimum infrastructure for effective integration of ICT in education. It includes the availability of computers for teachers and students, electricity, Internet access and competences in the subject area. The findings of the study are based on the same issues in the context of Tanzania.

\section{A. ICT Capacity Building for Secondary School Teachers}

MoESTVT has constantly been providing training to secondary school teachers to equip them with knowledge and skills for integrating ICT in teaching, learning and administration processes. These training programmes are divided into three major cycles, teachers are currently taught in two cycles comprising of topics shown in Table I.
Cycle Three consists of two important topics: Introduction to Databases, Database implementation Using MS Access and the Use of ICT in Teaching and Learning. The cascade mode of training is being employed where the National Facilitators trained teachers (named Master Trainers (MTs) in fifty nucleus schools who met at one training center. After the training, the Master Trainers were assessed; those who qualified were certified to train other teachers at the secondary schools. All Master Trainers are responsible to disseminate ICT knowledge and skills through In-Service training to other secondary school teachers while National facilitator will continue to monitor the quality of training to ensure validity and reliability.

\begin{tabular}{|l|l|}
\hline \multicolumn{1}{|c|}{ Cycle One } & \multicolumn{1}{c|}{ Cycle Two } \\
\hline Potentials of ICT & Multimedia \\
\hline Computer Fundamentals & Hardware Installation \\
\hline Operating Systems & $\begin{array}{l}\text { Software Installation and } \\
\text { Configuration }\end{array}$ \\
\hline MS Word & $\begin{array}{l}\text { Maintenance and Troubleshooting } \\
\text { of ICT Devices }\end{array}$ \\
\hline MS Spreadsheet & Safety of ICT Devices \\
\hline MS PowerPoint & Desktop Publishing \\
\hline Computer Networks and Internet & \\
\hline
\end{tabular}

\section{B. Laptop and Smartphone Ownership}

Out of 202 teachers who responded to the questionnaire, $69.3 \%$ owned laptops where as $84.7 \%$ possessed smartphone. It is evident that smartphone penetration is increasing at high rate and effective use of it in teaching and learning could be of great importance to the society as presented in Fig. 1.

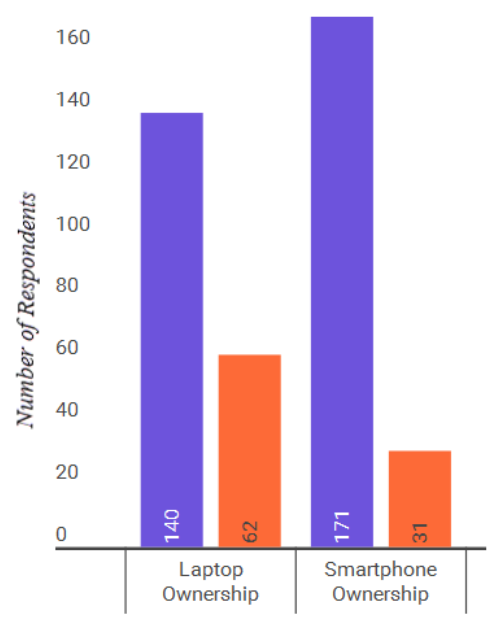

Fig. 1. Laptop and smartphone ownership.

\section{Application of ICT Skills}

After training Master Trainers, a study was done to find the readiness of teachers to use ICT devices in their schools. Fig. 2 shows the responses of teachers. Teachers are ready to apply the ICT skills they receive to improve their teaching and learning experience.

\section{ICT Infrastructure in the Schools}

The study also aimed at looking on number of ICT devices, 
including computers, present in the selected Secondary Schools. Table II shows selected schools, total number of students in the school and the number of computers present. From Table II, it can be seen that students to computer ratio in all schools is above 20. This implies that more efforts need to be done to provide ICT devices to schools which will lower the ratio to reach at most 5 .

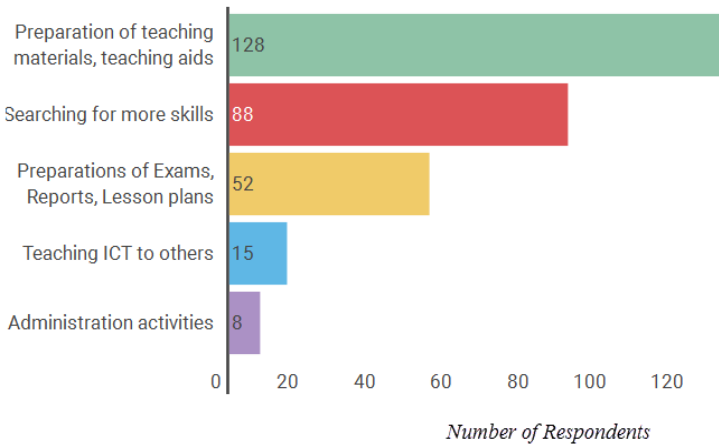

Fig. 2. Readiness responses for teachers to use ICTs in pedagogical practices.
Apart from computers, each surveyed school in Table II has one 62 inch Smart TV screen and at least one projector, all of which are used in teaching sessions. Other schools have Internet connections which are used by students and teachers to search for materials.

\section{DISCUSSION}

The study found out that many schools did not have enough ICT devices for effective integration of ICT in teaching and learning. The number of computers and other ICT devices and tools present in the selected schools is small compared to the total number of students in each school. Findings by [11] suggest that, the increased number of ICT devices should go with teachers training on how best ICT can be used as a subject and how it can be used in improving teaching of other subjects.

TABLE II: AVAILABILITY OF COMPUTERS IN SCHOOLS

\begin{tabular}{|c|c|c|c|c|c|}
\hline S/No & Secondary School Name & Region & $\begin{array}{c}\text { Approx. Number of } \\
\text { Students }\end{array}$ & $\begin{array}{l}\text { No of working } \\
\text { Computers }\end{array}$ & $\begin{array}{c}\text { Students to Computer } \\
\text { ratio }\end{array}$ \\
\hline 1 & Azania & Dar es Salaam & 2000 & 50 & 40 \\
\hline 2 & Jangwani & Dar es Salaam & 1100 & 50 & 22 \\
\hline 3 & Rajani & Shinyanga & 253 & 25 & 10.1 \\
\hline 4 & Mpwapwa & Dodoma & 630 & 24 & 26.3 \\
\hline 5 & Langasani & Kilimanjaro & 900 & 20 & 45 \\
\hline 6 & Kilwa & Lindi & 500 & 20 & 25 \\
\hline 7 & Longido & Arusha & 1650 & 15 & 110 \\
\hline 8 & Masasi Day & Mtwara & 533 & 13 & 41 \\
\hline 9 & Uhuru & Shinyanga & 813 & 12 & 67.8 \\
\hline 10 & Mawenzi & Kilimanjaro & 1300 & 12 & 108.3 \\
\hline 11 & Iringa Girls & Iringa & 997 & 12 & 83.1 \\
\hline 12 & Bukoba & Kagera & 684 & 10 & 68.4 \\
\hline 13 & Dr. Salmin Amour & Singida & 700 & 10 & 70 \\
\hline 14 & Korogwe Girls & Tanga & 1000 & 10 & 100 \\
\hline 15 & Tanga Technical & Tanga & 1000 & 10 & 100 \\
\hline 16 & Makambako & Njombe & 1200 & 10 & 120 \\
\hline
\end{tabular}

On the other hand, the findings revealed that most of the secondary school teachers (77.0\%)-possess either a laptop or a smartphone or both. This is an implication that they are ready to use such tools in the teaching and learning process if they are directed how best they can be used. Majority of the teachers $(95.5 \%)$ are even ready to spend some money for buying a few ICT devices such as modem, mouse, smartphone, laptop for ICT personal use, which is a motivation that whenever they have the know-how, they can do more with the devices.

On ICT readiness, teachers were asked whether they are ready to improve their teaching and learning style. All of the teachers $(100 \%)$ were ready to change and be able to apply the skills obtained to improve his or her pedagogical practices.

\section{RESULTS}

\section{A. Suggestions to Improve ICT Usage in Teaching and Learning}

To make effective integration of ICT at secondary school level, teachers suggested a number of key issues that need to 
be addressed. In many schools, it was found that, lack of the appropriate infrastructure was a major problem. Provision or increase of ICT infrastructure will accelerate the process of ICT integration in schools which will make teachers and students able to use them for the intended purpose. This will help in imparting ICT skills to students which are among the $21^{\text {st }}$ century skills [12]. Fig. 3 presents the different suggestions made by teachers to improve the use of ICT in the process of teaching and learning.

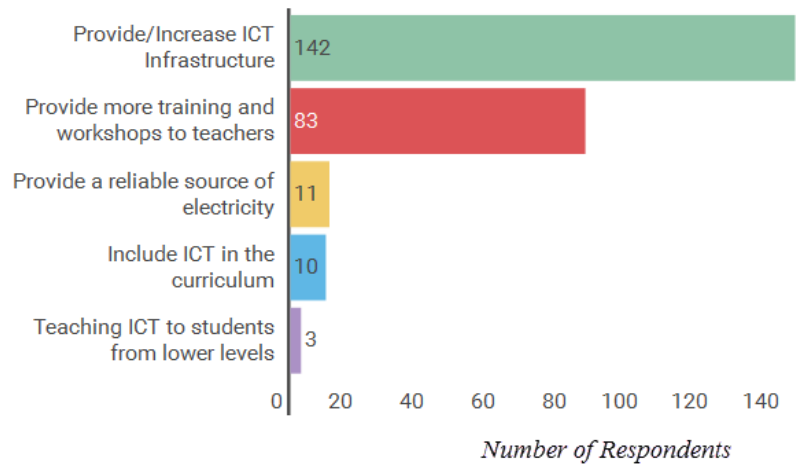

Fig. 3. Suggestions made by teachers to accelerate ICT integration.

\section{CONCLUSION AND WAY FORWARD}

This study has explored the readiness of the secondary schools in Tanzania to use ICT in teaching and learning. Moreover, it has also explored the possession of gadgets by teachers in the effort to make effective use of ICT in the pedagogical process. It can be suggested that, for effective ICT integration in teaching and learning, the Ministry of Education, Science, Technology and Vocational Training need to address the following: firstly, establishment of the relevant ICT infrastructure including provision of relevant, up to date ICT devices (computers, projectors, high speed Internet connection) to schools. Again, providing teachers with ICT knowledge and skills allow them to do many things. ICT will facilitate the work of teachers: Work less, produce a lot, and achieve more (time savings). ICT will motivate students to learn (nowadays, most of students are not motivated to learn). We must motivate them because motivation plays a big role in the learning process. In this case, teachers' role will be guiding students on how effectively ICT can be used to improve their learning experience. Moreover, the National ICT Policy should be revised to reflect all the activities related to ICT integration in teaching and learning.

\section{ACKNOWLEDGEMENT}

I would like to acknowledge F. Ishengoma and S. Banele for useful comments and corrections when editing and reviewing my manuscript.

\section{REFERENCES}

[1] R. Budhiraja and S. Sachdeva, "E-readiness assessment (India)," 2011

[2] United Republic of Tanzania, Planning Commission, "The Tanzania Development Vision 2025," Dar es Salaam, Tanzania, 2010.

[3] United Republic of Tanzania, Ministry of Finance, National Bureau of Statistics, "Tanzania in figures 2014," Dar es Salaam, Tanzania, 2015

[4] United Republic of Tanzania, Ministry of Education and Vocational Training, "National ICT for secondary school report," Dar es Salaam, Tanzania, 2015.

[5] A. Malero, A. Ismail, and M. Manyilizu, "ICT usage readiness for private and public secondary schools in Tanzania , a case of dodoma municipality," International Journal of Computer Applications., vol. 129, no. 3, pp. 2013-2016, 2015.

[6] United Republic of Tanzania, Ministry of Communications and Transport, "National information and communications technologies policy," Dar es Salaam, Tanzania, 2003.

[7] United Republic of Tanzania, Ministry of Education and Vocational Training, "Information and communication technology (ICT) policy for basic education," Dar es Salaam, Tanzania, 2007.

[8] S. Abdulwahed, A. Ismail, A. G. Almekhlafi, and M. H. Al-mekhlafy, "Teac hers' p erceptions of the use of technology in teaching languages in United Arab Emirates' schools," International Journal for Research in Education, no. 27, 2010.

[9] A. Mwalongo, "Teachers' perceptions about ICT for teaching, professional development, administration and personal use Alcuin Mwalongo Dar es Salaam University College of Education, Tanzania," International Journal of Educational Development Using Information and Communications Technologies, vol. 7, no. 3, pp. 36-49, 2011.

[10] United Nations Educational Scientific and Cultural Organisations, "Guide to measuring information and communication technologies (ICT) in education," Quebec, Canada, 2009.

[11] S. Amuko, M. Miheso, and S. Ndeuthi, "Opportunities and challenges Integration of ICT in teaching and learning mathematics in secondary schools, Nairobi , Kenya," Journal of Education and Practice., vol. 6 , no. 24 , pp. $1-7,2015$.

[12] O. M. Muhoza et al.,"Viewpoints to ICT practices and hinderances in Tanzanian secondary schools and teacher training colleges-focus on classroom teachers, Stockholm, Sweden," presented at 2014 International Conference on Teaching and Learning in Computing and Engineering.

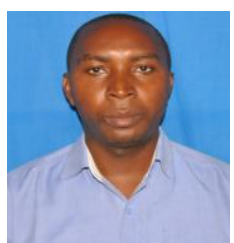

Lucian V. Ngeze is a lecturer in the University of Dodoma, Tanzania. He completed his B.Tech in electronics and communication engineering from the University of Kerala, India in 2009 . He then obtained his master of science in telecommunications engineering degree from the University of Dodoma Tanzania, in November, 2012. Mr. Ngeze joined the University of Dodoma as a tutorial assistant in 2010 . He is currently working as a lecturer. He has several certificates on e-learning, digital content development and ICT integration in teaching and learning. Mr. Ngeze is involved in many activities involving the integration of ict in teaching and learning and development of digital educational contents for primary and secondary schools in Tanzania. His current areas of research interest include: e-learning course design, development and implementation, virtual education technologies, ICT in education and e-content development. 